\title{
Caldimonas manganoxidans gen. nov., sp. nov., a poly(3-hydroxybutyrate)-degrading, manganese-oxidizing thermophile
}

\footnotetext{
${ }^{1}$ Division of Materials Science and Chemical Engineering, Faculty of Engineering, Yokohama National University, Yokohama, Kanagawa 240-8501, Japan

${ }^{2}$ Research Institute of Biological Resources, National Institute of Advanced Industrial Science and Technology, Tsukuba, Ibaraki 305-8566, Japan

${ }^{3}$ Section of Microbiology, Division of Biological Sciences, Cornell University, Ithaca, NY 14853-8101, USA
}

\author{
Minoru Takeda, ${ }^{1}$ Yoichi Kamagata, ${ }^{2}$ William C. Ghiorse, ${ }^{3}$ Satoshi Hanada ${ }^{2}$ \\ and Jun-ichi Koizumi ${ }^{1}$
}

\author{
Author for correspondence: Minoru Takeda. Tel: +81 45339 4266. Fax: +81453394267. \\ e-mail:mtake@ynu.ac.jp
}

A poly(3-hydroxybutyrate) (PHB)-degrading, Gram-negative, aerobic bacterium, strain $\mathrm{HS}^{\top}$, was isolated from a hot spring and chemotaxonomically and phylogenetically characterized. The oxidase-positive, weakly catalase-positive, non-pigmented cells $(0.6 \times 2.6 \mu \mathrm{m})$ exhibited a single polar flagellum and accumulated PHB granules. Strain $\mathrm{HS}^{\top}$ was capable of manganese oxidation. Highest growth rate was attained at $50^{\circ} \mathrm{C}$. The optimum $\mathrm{pH}$ for growth was 7-8. The major respiratory quinone was ubiquinone-8 and major cellular fatty acids were $C_{16: 0}, C_{16: 1}$ and $C_{18: 1}$. The $G+C$ content of the DNA was $66.2 \mathrm{~mol} \%$. Comparative 16S rDNA analysis indicated that strain $\mathrm{HS}^{\top}$ is related to the Rubrivivax subgroup and the family Comamonadaceae. The nearest phylogenetic relatives were Ideonella dechloratans ( $92.1 \%$ similarity), Leptothrix discophora (93.6\%), Roseateles depolymerans (92.4\%) and Rubrivivax gelatinosus (92.2\%). On the basis of its phylogenetic and phenotypic properties, it is proposed that this isolate be designated Caldimonas manganoxidans gen. nov., sp. nov.; the type strain is HS $^{\top}$ $\left(=\right.$ JCM $10698^{\top}=$ IFO $16448^{\top}=$ ATCC BAA-369' $)$.

Keywords: thermophile, manganese oxidation, poly(3-hydroxybutyrate) degradation, hot spring, Caldimonas manganoxidans

\section{INTRODUCTION}

Poly(3-hydroxybutyrate) (PHB) is a carbon and energy storage material of micro-organisms. PHB is physiologically related to polypropylene and polyethylene (Howells, 1982; Byrom, 1987). Biological degradation of PHB and related polymers have been extensively studied in Alcaligenes, Ralstonia, Bacillus, Pseudomonas and Comamonas strains that grow optimally at moderate temperatures (Blandl et al., 1995; Jendrossek et al., 1996). In a previous study, a moderately thermophilic bacterium capable of PHB degradation was isolated from a hot spring in Matsue, Japan, and its extracellular PHB depolymerase was purified and characterized (Takeda et al., 1998). The gene encoding the polymerase was identified and expressed in Escherichia coli (Takeda et al., 2000). The gene exhibited a

Abbreviation: PHB, poly(3-hydroxybutyrate).

The GenBank/EMBL/DDBJ accession number for the 165 rRNA gene sequence of strain $\mathrm{HS}^{\top}$ is $A B 008801$. similarity to the PHB depolymerase genes of Comamonas spp. The isolate (strain $\mathrm{HS}^{\mathrm{T}}$ ) is a Gramnegative, aerobic, rod-shaped bacterium that grows optimally at $45-50{ }^{\circ} \mathrm{C}$. It has also been suggested that the isolate was oxidized manganese (Takeda et al., 1998), a property shared by a number of other bacteria, including members of the genus Leptothrix (Ghiorse, 1984), which are known for their capacity to deposit iron and manganese oxides. In natural ecosystems and under some cultural conditions, Leptothrix spp. characteristically form sheaths comprised of protein and polysaccharide fibrils and the sheaths are encrusted with iron or manganese oxides (Emerson \& Ghiorse, 1992, 1993a, b). Leptothrix cholodnii SP-6 (formerly Leptothrix discophora SP-6) (Spring et al., 1996) is a well-studied manganese-oxidizing bacterium whose oxidizing activity is associated with the sheath (Emerson \& Ghiorse, 1992). Our preliminary phylogenetic analysis based on $16 \mathrm{~S}$ rDNA using the FASTDNAML program (Olsen et al., 1994) indicated that strain $\mathrm{HS}^{\mathrm{T}}$ is closely related to Comamonas testosteroni and Leptothrix spp. (Takeda et al., 1998). 
The current paper reports more detailed chemotaxonomic and phylogenetic characteristics of strain $\mathrm{HS}^{\mathrm{T}}$ compared with those of several related taxa. It is proposed that strain $\mathrm{HS}^{\mathrm{T}}$ represents a new species of a new genus, designated Caldimonas manganoxidans gen. nov., sp. nov.

\section{METHODS}

Cultivation. Strain $\mathrm{HS}^{\mathrm{T}}$ was isolated from a hot spring as a thermophilic PHB-degrading bacterium (Takeda et al., 1998). Unless otherwise described, it was cultivated without shaking in PYG medium (Adams \& Ghiorse, 1986a). To maintain the $\mathrm{pH}$ of the medium, $2 \cdot 38 \mathrm{~g} \mathrm{HEPES}{ }^{-1}$ was added and the $\mathrm{pH}$ was adjusted to $7 \cdot 2$ with $\mathrm{NaOH}$ before autoclaving. After cultivation, cells were harvested by centrifugation.

Quinone analysis. Quinones were extracted from lyophilized cells with chloroform-methanol $(2: 1, \mathrm{v} / \mathrm{v})$. The extract was passed through a Sep-Pak Plus column (Waters) and analysed by reverse-phase HPLC (Beckman System Gold with a Hewlett Packard Zorbox ODS column) for identification (Tamaoka et al., 1983).

Cellular fatty acid analysis. Cellular fatty acids were converted to methyl esters by treatment with anhydrous methanolic $\mathrm{HCl}$. The methyl esters were analysed using a Hitachi M7200A GC/3DQMS system equipped with a DB-5ms capillary column $(30 \mathrm{~m} \times 0.25 \mathrm{~mm} ; \mathrm{J} \& \mathrm{~W}$ Scientific) coated with (5\%-phenyl)-methylpolysiloxane (thickness $250 \mathrm{~nm})$. Helium was used as the carrier gas at a flow rate of $1.5 \mathrm{ml}$ $\mathrm{min}^{-1}$. The column temperature profile was as follows: $100{ }^{\circ} \mathrm{C}$ for $1 \mathrm{~min}$, then increased to $280^{\circ} \mathrm{C}$ at a rate of $18{ }^{\circ} \mathrm{C} \mathrm{min}^{-1}$ and held at $280{ }^{\circ} \mathrm{C}$ for $12 \mathrm{~min}$.

Electron microscopy. For visualization of the flagella, cells were statically grown for $24 \mathrm{~h}$ in the absence of manganese. Cells were harvested by centrifugation and negatively stained with $2 \%(\mathrm{w} / \mathrm{v})$ uranyl acetate, then subjected to transmission electron microscopy (Phillips EM 300). Cells for thin-section electron microscopy were fixed with $5 \%$ $(\mathrm{w} / \mathrm{v})$ glutaraldehyde for $6 \mathrm{~h}$ and then post-fixed in $2 \%$ (w/v) osmium tetraoxide at $4{ }^{\circ} \mathrm{C}$ for $3 \mathrm{~h}$. The fixed cells were stained with uranyl acetate for $1 \mathrm{~h}$ at room temperature, dehydrated and embedded in Spurr low-viscosity resin. Thin sections of the cells were made with an ultramicrotome (Reichert ULTRACUN) and were examined using a transmission electron microscope (Hitachi H7000).

DNA base composition. Total DNA of cells of strain $\mathrm{HS}^{\mathrm{T}}$ was extracted according to the procedure of Saito \& Miura (1963). Total DNA was digested with P1 nuclease using a Yamasa GC kit (Yamasa Shoyu). The $\mathrm{G}+\mathrm{C}$ content of the total DNA was measured by HPLC (Kamagata \& Mikami, 1991). The reference standard was an equimolar mixture of deoxyribonucleotides included in the kit.

Substrate utilization and growth factor requirement. The capability to utilize various carbon sources was tested on a basal medium containing $\left(1^{-1}\right)$ : $5 \mathrm{~g}$ (carbohydrates and complex organic compounds) or $1 \mathrm{~g}$ (organic acids) carbon source; $3 \mathrm{~g}\left(\mathrm{NH}_{4}\right)_{2} \mathrm{SO}_{4} ; 2.6 \mathrm{~g} \mathrm{~K}_{2} \mathrm{HPO}_{4} ; 0 \cdot 1 \mathrm{~g} \mathrm{NaH} \mathrm{PO}_{4}$; and $0.2 \mathrm{~g} \mathrm{MgSO}_{4} .7 \mathrm{H}_{2} \mathrm{O}$. All cultures were incubated for $3 \mathrm{~d}$. Substrate utilization was determined by monitoring the increase in OD at $660 \mathrm{~nm}$. Strain $\mathrm{HS}^{\mathrm{T}}$ was cultured in a medium containing $2 \mathrm{~g}$ glucose, $3 \mathrm{~g}\left(\mathrm{NH}_{4}\right)_{2} \mathrm{SO}_{4}, 2.6 \mathrm{~g}$ $\mathrm{K}_{2} \mathrm{HPO}_{4}, 0 \cdot 1 \mathrm{~g} \mathrm{NaH}_{2} \mathrm{PO}_{4}$ and $0 \cdot 2 \mathrm{~g} \mathrm{MgSO}_{4} .7 \mathrm{H}_{2} \mathrm{O}$ for $3 \mathrm{~d}$. After cultivation, a $0 \cdot 1$ vol. of the culture was recovered and inoculated into the same medium. This procedure was repeated three times. Growth factor requirement was determined based on whether or not the final culture became turbid.

Determination of PHB accumulation. Cells grown in a test tube for $24 \mathrm{~h}$ were fixed onto a glass microscope slide with poly-L-lysine and stained with the Nile red component of Nile blue A (Ostle \& Holt, 1982). Orange fluorescence observed in the highly refractile granules of the cells under short-wavelength epi-illumination using a Zeiss LSM-210 microscope established the presence of PHB in the granules.

Manganese oxidation. The extracellular accumulation of manganic oxide during growth of strain $\mathrm{HS}^{\mathrm{T}}$ was examined on PYG agar plates supplemented with various concentrations $(0-10 \mathrm{mM})$ of $\mathrm{Mn}^{2+}$ (as $\mathrm{MnSO}_{4} \cdot 2 \mathrm{H}_{2} \mathrm{O}$ ). The plates were incubated at $47^{\circ} \mathrm{C}$ for $7 \mathrm{~d}$ and the presence of brownish manganic oxide deposits in the colonies was confirmed by the addition of Leucoberbelin blue reagent (Ghiorse \& Hirsch, 1979).

Catalase and oxidase activities. Catalase activity was assayed with $3 \%(\mathrm{w} / \mathrm{v})$ hydrogen peroxide solution. Oxidase activity was assayed by applying the cells to a moistened commercial test paper strip (Nissui Pharmaceutical). Cells for these tests were cultured on PYG medium for $24 \mathrm{~h}$ without added $\mathrm{Mn}^{2+}$, as manganic oxides will oxidize the hydrogen peroxide giving a false-positive result.

Effects of temperature and $\mathrm{pH}$ on growth. Strain $\mathrm{HS}^{\mathrm{T}}$ was inoculated in nutrient broth and incubated at various temperatures with shaking. At intervals of $1-2 \mathrm{~h}$, the OD at $660 \mathrm{~nm}$ was measured and the specific growth rate $\left(\mathrm{h}^{-1}\right)$ was calculated. The $\mathrm{pH}$ of nutrient broth was adjusted to $\mathrm{pH}$ 4-10 by the addition of $2 \mathrm{M} \mathrm{NaOH}$ or $2 \mathrm{M} \mathrm{HCl}$. The medium was then sterilized by filtration. After inoculation, the cultures were incubated for $24 \mathrm{~h}$. Growth was judged by the increase in OD at $660 \mathrm{~nm}$. Salt tolerance was evaluated in nutrient broth supplemented with $0-4 \%$ (w/v) $\mathrm{NaCl}$. After inoculation of strain $\mathrm{HS}^{\mathrm{T}}$, cultures were shaken at $47^{\circ} \mathrm{C}$ for $18 \mathrm{~h}$. Cultures that showed visible turbidity were scored as tolerant.

Other physiological characterizations. Anaerobic growth was tested by the formation of colonies on PYG agar plates within $5 \mathrm{~d}$ in the BBL GasPack Pouch (Becton Dickinson Microbiology Systems). Gram staining was performed using $24 \mathrm{~h}$ old cells grown on PYG and nutrient broth at $47^{\circ} \mathrm{C}$ by a commercially available Gram definition kit (Favour-G set$\mathrm{S}$ 'Nissui'; Nissui Pharmaceutical). The motility of individual cells ( $24 \mathrm{~h}$ old) was determined by light microscopic observation.

$16 S$ rRNA gene sequence and phylogenetic analysis. Almost the full length of the $16 \mathrm{~S}$ rDNA sequence was previously determined (Takeda et al., 1998). It was aligned with reference sequences by CLUSTAL w (Thompson et al., 1994). Alignment gaps and ambiguous bases were not taken into consideration and 1210 bases were compared. A phylogenetic tree was constructed from the evolutionary distance matrix calculated by the neighbour-joining method (Saitou $\&$ Nei, 1987). The neighbour-joining analysis was performed with a MEGA program (Kumar et al., 1993). Bootstrap resampling analysis (Felsenstein, 1985) for 100 replicates was performed in order to estimate the confidence of topologies. 


\section{RESULTS AND DISCUSSION}

\section{Manganese oxidation}

Strain $\mathrm{HS}^{\mathrm{T}}$ formed colonies on PYG plates containing 0-4 mM $\mathrm{Mn}^{2+}$ within $4 \mathrm{~d}$. Only a few small colonies appeared after incubation for $7 \mathrm{~d}$ on plates containing $5 \mathrm{mM} \mathrm{Mn}{ }^{2+}$. No colonies formed even after 2 weeks on

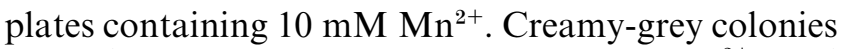
formed on plates containing $0-1 \mathrm{mM} \mathrm{Mn}^{2+}$ and slightly brownish colonies formed on those containing 2-5 $\mathrm{mM} \mathrm{Mn}^{2+}$. Reaction with Leucoberbelin blue reagent revealed formation of manganese oxide in colonies appearing on the plates containing $0 \cdot 5-5 \cdot 0$ $\mathrm{mM} \mathrm{Mn}^{2+}$, whereas no comparable reaction occurred on plates supplied with lower concentrations $(0 \cdot 0-0 \cdot 1$ $\mathrm{mM}$ ) of $\mathrm{Mn}^{2+}$. Colonies grown with $2 \mathrm{mM} \mathrm{Mn}^{2+}$ very quickly turned blue upon the addition of Leucoberbelin blue reagent. Additionally, slightly brownish coloured zones, presumably attributable to the forma-

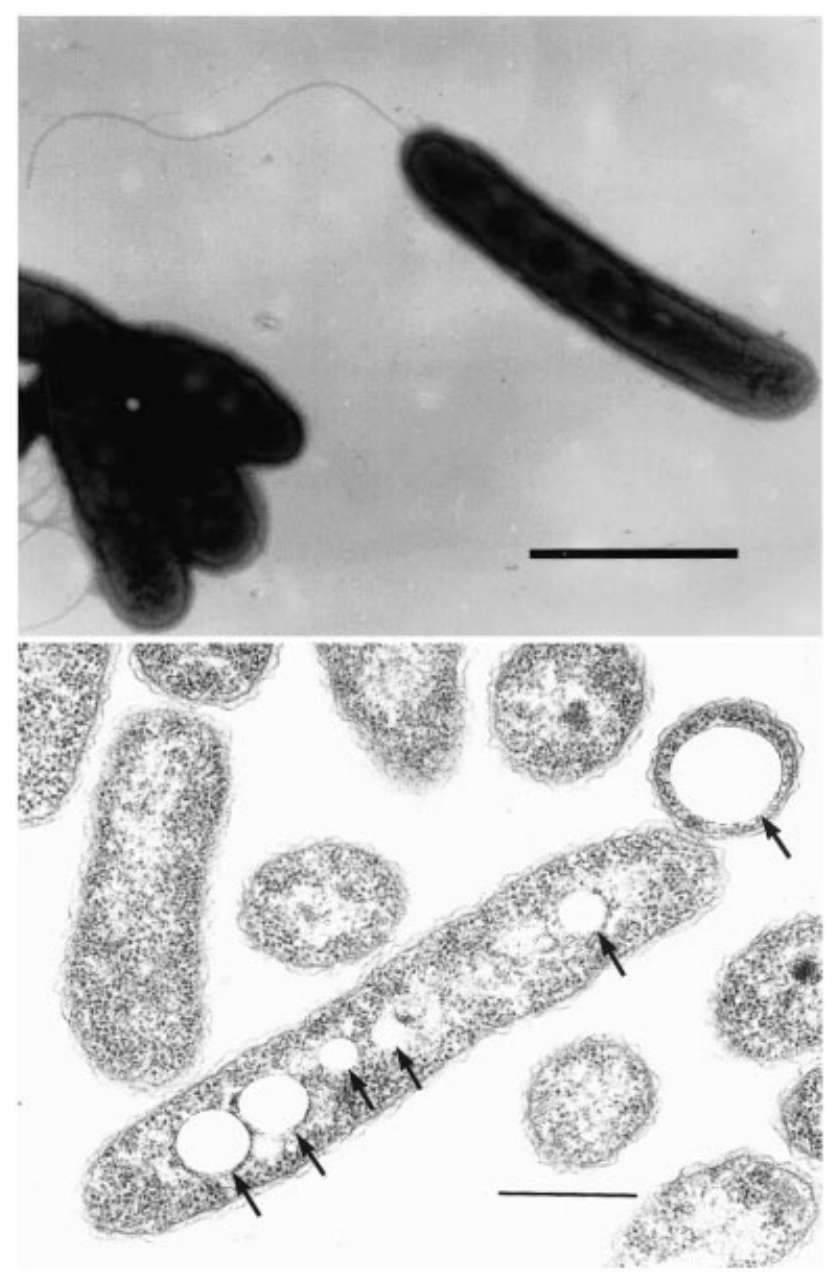

Fig. 1. Negatively stained electron micrograph (top; bar, $1 \mu \mathrm{m}$ ) and thin section micrograph (bottom; bar, $0.5 \mu \mathrm{m}$ ) of strain $\mathrm{HS}^{\top}$. The cell bears single polar flagellum (top). Note the electrontransparent intracellular granules (indicated by arrows) and absence of extracellular sheath structure (bottom). tion of manganese oxides, formed around the colonies in plates containing 2 and $3 \mathrm{mM} \mathrm{Mn}^{2+}$.

\section{Morphology}

Colonies of strain $\mathrm{HS}^{\mathrm{T}}$ on PYG agar or nutrient agar plates were creamy-grey. No diffusible pigment was produced. Granular cell clumps were often observed in liquid culture. The number and size of the clumps increased in the presence of $\mathrm{Mn}^{2+}$. Neither filamentous cellular clumps nor sheath formation were observed. Motile cells were observed under the microscope especially in the younger stage of culture without shaking. As shown in Fig. 1(top), strain $\mathrm{HS}^{\mathrm{T}}$ had a single polar flagellum. A number of electron-transparent granules were detected by transmission electron microscopy (Fig. 1, bottom). These granules were probably composed of PHB because PHB granules were recognized in Nile red-stained cells by epifluorescence microscopy. The presence of PHB in cells of strain $\mathrm{HS}^{\mathrm{T}}$ was previously revealed by GLC (Takeda et al., 1998). Cells of strain $\mathrm{HS}^{\mathrm{T}}$ were straight rods $0.5-0.7 \mu \mathrm{m}$ wide and $2 \cdot 2-3.5 \mu \mathrm{m}$ long (Fig. 1). Spores were not observed. Gram-staining was negative. The cells possessed a typical Gram-negative cell wall structure (Fig. 1, bottom).

\section{Substrate utilization and growth properties}

Strain $\mathrm{HS}^{\mathrm{T}}$ was a chemo-organotrophic bacterium and only grew aerobically. Its optimum growth temperature was $50{ }^{\circ} \mathrm{C}$ and growth was not detected at $65^{\circ} \mathrm{C}$. The $\mathrm{pH}$ for optimum growth was between 8 and 9. It was oxidase-positive and weakly catalase-positive. Growth factors were not required. Strain $\mathrm{HS}^{\mathrm{T}}$ was able to grow at $\mathrm{NaCl}$ concentrations ranging from 0 to $2 \%$ $(\mathrm{w} / \mathrm{v})$, but not at 3 or $4 \%$.

Growth of strain $\mathrm{HS}^{\mathrm{T}}$ was not observed on the following substrates: D-glucosamine, myo-inositol, D-arabinose, L-fucose, D-xylose, D-salicin, trehalose, D-mannose, D-fructose, D-ribose, lactose, L-rhamnose, raffinose, propionate, 4-hydroxybutyrate, oxalate, quinate, acetate and glucuronate. Strain $\mathrm{HS}^{\mathrm{T}}$ did grow on D-sorbitol, maltose, sucrose, D-glucose, mannitol, D-galactose, starch, glycerol, L-malate, lactate, citrate, tartrate, succinate, pyruvate, gluconate, malonate, 3hydroxybutyrate, beef extract, yeast extract, malt extract, tryptone, Casamino acids and peptone. Vigorous growth was observed on beef extract, yeast extract, tryptone, peptone and gluconate.

\section{Chemotaxonomic characteristics}

The major respiratory quinone of strain $\mathrm{HS}^{\mathrm{T}}$ was ubiquinone- 8 . The main cellular fatty acids were $\mathrm{C}_{16: 0}$ (42\% of the total cellular fatty acid methyl ester detected), $\mathrm{C}_{16: 1}(19 \%)$, and $\mathrm{C}_{18: 1}(16 \%)$. Small amounts $(2-5 \%)$ of $3-\mathrm{OH} \mathrm{C}_{10: 0}, \mathrm{C}_{12: 0}, \mathrm{C}_{14: 0}, \mathrm{C}_{14: 0}$, $\mathrm{C}_{15: 0}, \mathrm{C}_{17: 1}$ (or cyclo $\mathrm{C}_{17: 0}$ and $\mathrm{C}_{18: 0}$ were also detected. 


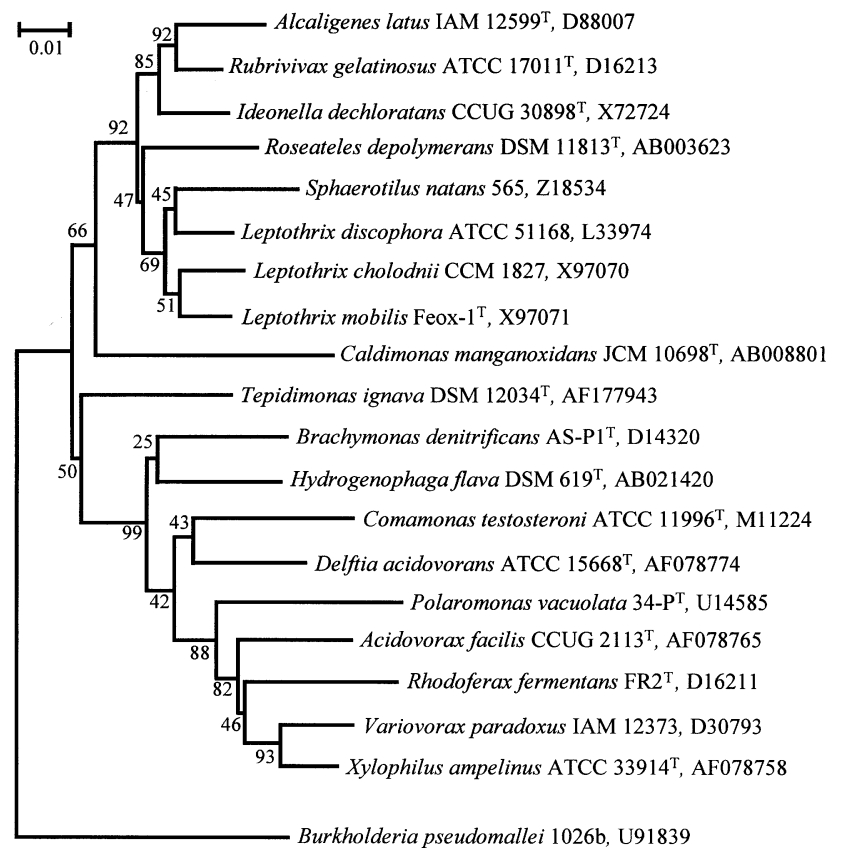

Fig. 2. Phylogenetic position of strain $H S^{\top}$ among the related strains of the $\beta$-Proteobacteria. The tree was constructed from the evolutionary distance matrix based on the neighbourjoining method (Saitou \& Nei, 1987). Bar, 1 nt substitution per $100 \mathrm{nt}$ in the $16 \mathrm{~S}$ rDNA sequence. The sequence of Burkholderia pseudomallei was used to root the tree. Bootstrap probabilities (Felsenstein, 1985) are indicated at the branch points. Sequence accession numbers are shown next to the strain names.

The $\mathrm{G}+\mathrm{C}$ content of the total DNA of strain $\mathrm{HS}^{\mathrm{T}}$ was $66 \cdot 2 \mathrm{~mol} \%$. The fatty acid composition and the lipoquinone are typical of the $\beta$-Proteobacteria.

\section{Phylogenetic analysis and phenotypic comparison}

Strain HS $^{\mathrm{T}}$ was closely related to the strains of the Rubrivivax subgroup and the family Comamonadaceae (Fig. 2). The nearest phylogenetic relatives of strain $\mathrm{HS}^{\mathrm{T}}$ were Ideonella dechloratans $(92 \cdot 1 \%$ similarity), $L$. discophora $(93.6 \%)$, Roseateles depolymerans $(92.4 \%)$ and Rubrivivax gelatinosus $(92 \cdot 2 \%)$.

Table 1 summarizes the properties of strain $\mathrm{HS}^{\mathrm{T}}$ that can differentiate it from phylogenetically related strains of the $\beta$-Proteobacteria. One of the interesting features of strain $\mathrm{HS}^{\mathrm{T}}$ was its ability to oxidize $\mathrm{Mn}^{2+}$. The ability has been found in L. discophora (Adams \& Ghiorse, 1986b; Emerson \& Ghiorse, 1992; Spring et al., 1996), which is the closest relative $(93.6 \% 16 \mathrm{~S}$ rDNA sequence similarity) to strain $\mathrm{HS}^{\mathrm{T}}$. However, strain $\mathrm{HS}^{\mathrm{T}}$ differed from $L$. discophora in that it had a higher growth temperature, was incapable of forming a sheath, had a lower $\mathrm{G}+\mathrm{C}$ content and in its carbon source utilization. Sphaerotilus natans is a close relative of $L$. discophora and forms sheaths, but cannot oxidize $\mathrm{Mn}^{2+}$ (Corstjens \& Muyzer, 1993; Siering \& Ghiorse, 1996). L. discophora grows at moderate temperatures, utilizes a wide variety of organic compounds and has a much larger cell size than strain $\mathrm{HS}^{\mathrm{T}}$, thus allowing an easy distinction between the two. Roseateles depolymerans has the ability to produce bacteriochlorophyll and carotenoids under certain conditions and forms several polar flagella; these two properties were not observed in strain $\mathrm{HS}^{\mathrm{T}}$. Rubrivivax gelatinosus is also a pigmented bacterium due to its bacteriochlorophyll and carotenoid production and can grow photosynthetically; strain $\mathrm{HS}^{\mathrm{T}}$ cannot grow photosynthetically. $I$. dechloratans can grow anaerobically by assimilating acetate which is different from strain $\mathrm{HS}^{\mathrm{T}}$. Alcaligenes

\section{Table 1. Characteristics of strain $\mathrm{HS}^{\top}$ and related species}

Taxa: 1, strain $\mathrm{HS}^{\mathrm{T}} ;$ 2, Leptothrix discophora; 3, Sphaerotilus natans; 4, Roseateles depolymerans; 5, Rubrivivax gelatinosus; 6 , Ideonella dechloratans; 7, Alcaligenes latus; and 8, Tepidimonas ignava. Data was obtained from the following references: Imhoff \& Trüper (1989); Kersters \& De Ley (1984); Malmqvist et al. (1994); Moreira et al. (2000); Palleroni \& Palleroni (1978); Suyama et al. (1998, 1999); Spring et al. (1996); and Willems et al. (1991a, b). +, $90 \%$ or more positive; -, $90 \%$ or more absent; d, $11-89 \%$ present; NT, not tested.

\begin{tabular}{|c|c|c|c|c|c|c|c|c|}
\hline Characteristic & 1 & 2 & 3 & 4 & 5 & 6 & 7 & 8 \\
\hline Cell size $(\mu \mathrm{m})$ & $0.5-0.7 \times 2 \cdot 2-3 \cdot 5$ & $0.6-1.4 \times 1.0-12.0$ & $1 \cdot 2-2 \cdot 5 \times 2 \cdot 0-10 \cdot 0$ & $0.5 \times 2.0$ & $0 \cdot 4-0.7 \times 1 \cdot 0-3 \cdot 0$ & $0 \cdot 7-1 \cdot 0 \times 2 \cdot 5-5 \cdot 0$ & $1.1-1.4 \times 1 \cdot 6-2.4$ & $0.5-1.0 \times 1.2-2.0$ \\
\hline Flagella & Single, polar & Single, polar & Polar bunch & Several, polar & Single, polar & Several, polar & 5-10, peritrichous & Single, polar \\
\hline Sheath formation & - & + & + & - & - & - & - & - \\
\hline Photosynthesis & - & - & - & - & + & - & - & - \\
\hline Pigments & - & - & - & + & + & - & - & - \\
\hline $\mathrm{Mn}^{2+}$ oxidation & + & + & - & NT & NT & NT & NT & NT \\
\hline Optimum temp. or range $\left({ }^{\circ} \mathrm{C}\right)$ & 50 & $15-33$ & $10-37$ & 35 & 35 & $12-42$ & 35 & $50-55$ \\
\hline \multicolumn{9}{|l|}{ Utilization of: } \\
\hline Acetate & - & - & + & d & + & + & - & + \\
\hline Lactate & + & - & + & + & + & + & + & + \\
\hline Pyruvate & + & + & + & + & + & + & - & + \\
\hline Citrate & + & - & + & + & + & NT & $\mathrm{d}$ & - \\
\hline Glycerol & + & + & + & - & - & NT & + & - \\
\hline Mannitol & + & NT & + & + & - & NT & - & - \\
\hline Sorbitol & + & NT & + & - & - & NT & - & - \\
\hline D-Fructose & - & - & + & + & + & + & + & - \\
\hline D-Glucose & + & + & + & + & + & + & + & - \\
\hline D-Galactose & + & NT & + & + & NT & NT & - & - \\
\hline Sucrose & + & + (not all strains) & + & - & NT & NT & + & - \\
\hline $\mathrm{G}+\mathrm{C}$ content $(\mathrm{mol} \%)$ & $66 \cdot 2$ & 71 & $69 \cdot 9$ & $66 \cdot 2-66 \cdot 3$ & $70 \cdot 0-72 \cdot 5$ & $68 \cdot 1$ & $69 \cdot 1-71 \cdot 1$ & 69 \\
\hline
\end{tabular}


latus is distinguishable from strain $\mathrm{HS}^{\mathrm{T}}$ by its short coccoid cell shape and the formation of peritrichous flagella. All these close relatives of strain $\mathrm{HS}^{\mathrm{T}}$ mentioned above are mesophilic. Tepidimonas ignava is the only thermophilic bacterium ever recognized in the related strains. Its optimum growth temperature of $50-55{ }^{\circ} \mathrm{C}$ is similar to that of strain $\mathrm{HS}^{\mathrm{T}}$. However, the following properties of T. ignava (Moreira et al., 2000) are different from those of strain $\mathrm{HS}^{\mathrm{T}}$ : no carbohydrate is assimilated; short rod cell shape; and one of the major cellular fatty acids is $\mathrm{C}_{17: 0}$.

On the basis of its phenotypic characteristics and $16 \mathrm{~S}$ rRNA gene analysis, it is proposed that strain $\mathrm{HS}^{\mathrm{T}}$ represents a new species of a new genus, for which the name Caldimonas manganoxidans gen. nov., sp. nov. is proposed.

\section{Description of the genus Caldimonas gen. nov.}

Caldimonas [Cal.di.mo'nas. L. adj. caldus hot; Gr. fem. n. monas unit, monad; N.L. fem. n. Caldimonas hot (heat-loving) monad].

Cells are motile by means of a single polar flagellum, especially during the early stages of culture without shaking. Gram-negative, aerobic rods $(0.5-0.7 \times 2 \cdot 2-$ $3.5 \mu \mathrm{m})$. Neither sheath formation nor filamentous growth is observed. Oxidase-positive and weakly catalase-positive. Optimum growth temperature and $\mathrm{pH}$ are $50^{\circ} \mathrm{C}$ and $8-9$, respectively. Many organic acids and carbohydrates are utilized. PHB granules are accumulated as storage material. Chemo-organotroph. The $\mathrm{G}+\mathrm{C}$ content of the DNA is around $66 \mathrm{~mol} \%$ and ubiquinone- 8 is the major quinone. The type species of the genus is Caldimonas manganoxidans.

\section{Description of Caldimonas manganoxidans sp. nov.}

Caldimonas manganoxidans (man.gan.ox'i.dans. N.L. neut. n. manganum manganese; M.L. part. adj. oxidans oxidizing; N.L. part. adj. manganoxidans manganese-oxidizing).

Cells are rods (average of $0.6 \times 2.6 \mu \mathrm{m}$ ), form granular clumps in media supplemented with manganese. Cells slowly and weakly oxidize manganese on agar plates supplemented with $0 \cdot 5-5 \cdot 0 \mathrm{mM} \mathrm{Mn}{ }^{2+}$. Colonies on PYG plates are circular, convex, opaque and creamygrey. Growth factors are not required. Growth is not observed in the presence of $3 \%(\mathrm{w} / \mathrm{v}) \mathrm{NaCl}$. Cultures are not maintained at $65^{\circ} \mathrm{C}$. The following compounds are utilized as energy and carbon sources: D-sorbitol, maltose, sucrose, D-glucose, mannitol, D-galactose, starch, glycerol, L-malate, lactate, citrate, tartrate, succinate, pyruvate, gluconate, malonate, 3 -hydroxybutyrate, beef extract, yeast extract, malt extract, tryptone, Casamino acids and peptone. In addition to these substrates, PHB is rapidly degraded and utilized. No growth observed on D-glucosamine, myo-inositol, D-arabinose, L-fucose, D-xylose, D-salicin, trehalose, D-mannose, D-fructose, D-ribose, lactose, L-rhamnose, raffinose, propionate, 4-hydroxybutyrate, oxalate, qui-nate, acetate or glucuronate. The major cellular fatty acids are $\mathrm{C}_{16: 0}, \mathrm{C}_{16: 1}$ and $\mathrm{C}_{18: 1}$. The type strain is $\mathrm{HS}^{\mathrm{T}}\left(=\mathrm{JCM} 10698^{\mathrm{T}}=\right.$ IFO $16448^{\mathrm{T}}=$ ATCC BAA$369^{\mathrm{T}}$ ). Isolated from a hot spring in Matsue, Japan.

\section{ACKNOWLEDGEMENTS}

We thank the following researchers at the National Institute of Advanced Industrial Science and Technology: Xian Ying Meng for transmission electron microscopy, Aiko Sukegawa for cultivation and Yasuo Ashizawa for quinone analysis and Yoko Ueda for determination of DNA base composition.

\section{REFERENCES}

Adams, L. F. \& Ghiorse, W. C. (1986a). Physiology and ultrastructure of Leptothrix discophora SS-1. Arch Microbiol 145, 126-135.

Adams, L. F. \& Ghiorse, W. C. (1986b). Influence of manganese on growth of a sheathless strain of Leptothrix discophora. Appl Environ Microbiol 49, 556-562.

Blandl, H., Bachofen, R., Mayer, J. \& Wintermantel, E. (1995). Degradation and applications of polyhydroxyalkanoates. Can J Microbiol 41, 143-153.

Byrom, D. (1987). Polymer synthesis by microorganisms: technology and economics. Trends Biotechnol 5, 246-250.

Corstjens, P. \& Muyzer, G. (1993). Phylogenetic analysis of the metaloxidizing bacteria Leptothrix discophora and Sphaerotilus natans using 16S rDNA sequence data. Syst Appl Microbiol 16, 219-223.

Emerson, D. \& Ghiorse, W. C. (1992). Isolation, cultural maintenance, and taxonomy of a sheath-forming strain of Leptothrix discophora and characterization of manganese-oxidizing activity associated with the sheath. Appl Environ Microbiol 58, 4001-4010.

Emerson, D. \& Ghiorse, W. C. (1993a). Ultrastructure and chemical composition of the sheath of Leptothrix discophora SP-6. J Bacteriol 175, 7808-7818.

Emerson, D. \& Ghiorse, W. C. (1993b). Role of disulfide bonds in maintaining the structural integrity of the sheath of Leptothrix discophora SP-6. J Bacteriol 175, 7819-7827.

Felsenstein, J. (1985). Confidence limits on phylogenies: an approach using the bootstrap. Evolution 39, 783-791.

Ghiorse, W. C. (1984). Biology of iron- and manganese-depositing bacteria. Annu Rev Microbiol 38, 515-550.

Ghiorse, W. C. \& Hirsch, P. (1984). An ultrastructural study of ion and manganese deposition associated with extracellular polymers of pedomicrobium-like budding bacteria. Arch Microbiol 123, 213-226.

Howells, E. R. (1982). Opportunities in biotechnology for the chemical industry. Chem Ind 8, 508-511.

Imhoff, J. F. \& Trüper, H. G. (1989). Genus Rhodocyclus Pfennig 1978, $285^{\mathrm{AL}}$. In Bergey's Manual of Systematic Bacteriology, vol. 3, pp. 1678-1682. Edited by J. T. Staley, M. P. Bryant, N. Pfennig \& J. G. Holt. Baltimore: Williams \& Wilkins.

Jendrossek, J., Schiremer, A. \& Schlegel, H. G. (1996). Biodegradation of polyhydroxyalkanoic acids. Appl Microbiol Biotechnol 46, 451-463.

Kamagata, Y. \& Mikami, E. (1991). Isolation and characterization of a novel thermophilic Methanosaeta strain. Int J Syst Bacteriol 41, 191-196.

Kersters, K. \& De Ley, J. (1984). Genus Alcaligenes Castellani and Chalmers 1919, 936 ${ }^{\text {AL }}$. In Bergey's Manual of Systematic Bacteriology, vol. 1, pp. 361-373. Edited by N. R. Krieg \& J. G. Holt. Baltimore: Williams \& Wilkins. 
Kumar, S., Tamura, K. \& Nei, M. (1993). MEGA: molecular evolutionary genetics analysis, version 1.0. Pennsylvania State University, University Park, PA 16802, USA.

Malmqvist, Å., Welander, T., Moor, E., Ternström, A., Molin, G. \& Stenstöm, I.-M. (1994). Ideonella dechloratans gen. nov., sp. nov., a new bacterium capable of growing anaerobically with chlorate as an electron acceptor. Syst Appl Microbiol 17, 58-64.

Moreira, C., Rainey, F. A., Nobre, M. F., da Silva, M. T. \& da Costa, M. S. (2000). Tepidimonas ignava gen. nov., sp. nov., a new chemolithoheterotrophic and slightly thermophilic member of the $\beta$-Proteobacteria. Int J Syst Evol Microbiol 50, 735-742.

Olsen, G. L., Matsuda, H., Hagstrom, R. \& Overbeek, T. J. (1994). FASTDNAML: a tool for construction of phylogenetic trees of DNA sequences using maximum likelihood. Comput Appl Biosci 10, 41-48.

Ostle, A. G. \& Holt, J. G. (1982). Nile blue A as fluorescent stain for poly- $\beta$-hydroxybutyrate. Appl Environ Microbiol 44, 238-241.

Palleroni, N. J. \& Palleroni, A. V. (1978). Alcaligenes latus, a new species of hydrogen-utilizing bacteria. Int J Syst Bacteriol 28, 416-424.

Saito, H. \& Miura, K. (1963). Preparation of transforming deoxyribonucleic acid by phenol treatment. Biochim Biophys Acta 72, 619-629.

Saitou, N. \& Nei, M. (1987). The neighbor-joining method: a new method for reconstructing phylogenetic trees. Mol Biol Evol 4, 406-425.

Siering, P. L. \& Ghiorse, W. C. (1996). Phylogeny of the SphaerotilusLeptothrix group inferred from morphological comparisons, genomic fingerprinting, and $16 \mathrm{~S}$ ribosomal DNA sequence analyses. Int $J$ Syst Bacteriol 46, 173-182.

Spring, S., Kämpfer, P., Ludwig, W. \& Schleifer, K.-H. (1996). Polyphasic characterization of the genus Leptothrix: new descriptions of Leptothrix mobilis sp. nov. and Leptothrix discophora sp. nov. nom. rev. and emended description of Leptothrix cholodnii emend. Syst Appl Microbiol 19, 634-643.
Suyama, T., Hosoya, H. \& Tokiwa, Y. (1998). Bacterial isolates degrading aliphatic polycarbonates. FEMS Microbiol Lett 161, 255261.

Suyama, T., Shigematsu, T., Takaichi, S., Nodasaka, Y., Fujikawa, S., Hosoya, H., Tokiwa, Y., Kanagawa, T. \& Hanada, S. (1999). Roseateles depolymerans gen. nov., sp. nov., a new bacteriochlorophyll $a$-containing obligate aerobe belonging to the $\beta$-subclass of the Proteobacteria. Int J Syst Bacteriol 49, 449-457.

Takeda, M., Koizumi, J., Yabe, K. \& Adachi, K. (1998). Thermostable poly(3-hydroxybutyrate) depolymerase of a thermophilic strain of Leptothrix sp. isolated from a hot spring. J Ferment Bioeng 85, 375-380.

Takeda, M., Kitashima, K., Adachi, K., Hanaoka, Y. \& Koizumi, J. (2000). Cloning and expression of the gene encoding thermostable poly(3-hydroxybutyrate) depolymerase. J Biosci Bioeng 90, 416-421.

Tamaoka, J., Katayama-Fujimura, Y. \& Kuraishi, H. (1983). Analysis of bacterial menaquinone mixtures by high performance liquid chromatography. J Appl Bacteriol 54, 31-36.

Thompson, J. D., Higgins, D. G. \& Gibson, T. J. (1994). Clustal W: improving the sensitivity of progressive multiple sequence alignment through sequence weighting, position-specific gap penalties and weight matrix choice. Nucleic Acids Res 22, 4673-4680.

Willems, A., De Ley, J., Gillis, M. \& Kersters, K. (1991a). Comamonadaceae, a new family encompassing the acidovorans rRNA complex, including Variovorax paradoxus gen. nov., comb. nov., for Alcaligenes paradoxus (Davis 1969). Int J Syst Bacteriol 41, 445-450.

Willems, A., Gillis, M. \& De Ley, J. (1991b). Transfer of Rhodocyclus gelatinosus to Rubrivivax gelatinosus gen. nov., comb. nov., and phylogenetic relationships with Leptothrix, Sphaerotilus natans, Pseudomonas saccharophila, and Alcaligenes latus. Int J Syst Bacteriol 41, $65-73$. 